\title{
I Can’t Be Racist-I Teach in an Urban School, and I'm a Nice White Lady!
}

\author{
Lisa A. Miller ${ }^{1, *} \&$ Victor W. Harris ${ }^{2}$ \\ ${ }^{1}$ Graduate student, Institute of Food and Agricultural Sciences, University of Florida, Gainesville, FL, USA \\ ${ }^{2}$ Faculty, Institute of Food and Agricultural Sciences, University of Florida, Gainesville, FL, USA \\ *Correspondence: Faculty, Institute of Food and Agricultural Sciences, University of Florida, Gainesville, FL, USA. \\ E-mail: lisa.kopp@ufl.edu
}

Received: March 22, 2018

Accepted: April 23, $2018 \quad$ Online Published: May 17, 2018

doi:10.5430/wje.v8n3p1

URL: https://doi.org/10.5430/wje.v8n3p1

\begin{abstract}
This paper examines, through the lens of critical race theory (CRT), beliefs often asserted by self-described, open-minded white educators about their students of color. While these teachers may perceive themselves as liberal and inclusive, their interactions with students of color are shrouded by white privilege which can be disenfranchising to students of color. By countering these ascribed beliefs with research, theory, and qualitative experiences, the authors aim to expose how white privilege manifests within the typical classroom and to invite all white educators to examine their racial attitudes and beliefs. Using CRT, the authors* make recommendations for strategies to develop white teachers into white allies.
\end{abstract}

Keywords: critical race theory, white teachers, students of color, African American, Latino

*Note: This article documents the experiences of the first author with theoretical and research contributions from the second author.

\section{Introduction}

In 2006, I relocated from a small, urban Midwestern city to Los Angeles, California. Inspired by the charter school movement, I wanted to put my newly minted teaching credential to use. A charter high school in East Los Angeles took a chance on me-a young white teacher who had more enthusiasm than experience. As I stood before my $10^{\text {th }}$-grade students - all Latino, predominately Mexican American-I realized how unprepared I was. I had no understanding of the community, very little prior interaction with people of color, and no context for why my students and their families immigrated to Los Angeles, including those who had done so illegally. Even more, I had no idea how to acknowledge my whiteness and their brownness and what that meant to them or me.

My experiences are not unique. Instead, they are incredibly common amongst white teachers in urban settings as United States schools grow increasingly diverse. Estimates for the 2019-2020 academic year put white students in the minority with the Latino American student population at 30\%, African American at 15\%, Asian American/Pacific Islander at 5.5\%, and Native American at 1\% (Howard \& Navarro, 2016). This reconfiguration in demographics will continue, with the white student population decreasing continuously over the next several decades. Estimates by the U.S. Department of Education are that by the year 2060, white students will account for only 35\% of the student population (Howard \& Navarro, 2016).

Despite these dramatic shifts in diversity, the response within our schools and teacher preparation programs remains unreflective. To verify this, we need look no further than the results: teacher preparation programs have done little to address a dynamic student population beyond superficial multicultural courses, the achievement gap still exists, children of color are more apt to drop out and are over-referred for discipline and special education services, and Black males, in particular, are characterized as disinterested in education (Harper \& Davis, 2012). School reform efforts have attempted to address these issues, particularly by closing the achievement gap, which has been dubbed the greatest civil rights issue of our time. Under the guise of neoliberal reform and bankrolled by white billionaires, these reform attempts have produced similar results. 
A more sensible explanation for disproportionate outcomes across racial and ethnic lines is the role race and racism play in school policies and practices (Howard \& Navarro, 2016). In other words, when children of color are mandated "to learn in schools where content, instruction, school culture, and assessment are often racially hostile, exclusive, and serve as impediments for school success," that does not come without a price, and our children of color are the ones who pay that price (Howard \& Navarro, 2016, p. 255). While there are many avenues to examine how white privilege and white supremacy manifest in the K-12 setting, this article will explore how it manifests in the teaching force.

As the U.S. population diversifies, educators have remained consistently white and female, accounting for $80 \%$ (Howard \& Navarro, 2016) to 90\% (Cooper, 2003; Naman, 2009) of the teaching force. Our homogenous teaching force should raise a major concern as many white teachers have had limited interactions with those who have racial or ethnic backgrounds different from their own. Because of this, they often feel underprepared to teach in a diverse setting (Henfield \& Washington, 2012). While one of the goals to address this issue would be for teacher education programs to make a radical shift, to rewrite their programming, or for schools to overhaul their professional development, the reality is that change takes time, and change takes advocacy. For true and lasting change to take place, it must begin with white teachers who are on the frontlines of education, and it is we who must make the radical shift from being part of the problem to part of the solution. This paper serves as a call to action for white educators everywhere to rethink their beliefs, attitudes, and actions with regard to diversity, inclusiveness, and competency to better serve children of color within their sphere of influence.

\section{Literature Review}

Children of color are more likely to have a white teacher than not. Research has explored the implications of white teachers' interactions with students of color, revealing the role of their Whiteness (Flintoff, Dowling \& Fitzgerald (2015), Henfield \& Washington (2012), Howard \& Navarro (2016), Ledesma \& Calderón (2015), Matias (2013), Matias \& Liou (2015). Wise (2008) explains that Whiteness is not about one's own physical or biological make-up, but a mindset that is a result of being the prevailing culture (as cited in Henfield \& Washington, 2012). From this mindset emerges dispositions and beliefs that are promulgated as universal and thus seep into all parts of our culture, such as politics, economics, education, and the law. This mindset (i.e., accepted systems and methods) "produces concrete systemic racism" that renders all the privileges that accompany white skin as not just normal, but "invisible" (Matias, 2013, p. 73). Wise (2008), a white male, applies the following analogy about the invisibleness of Whiteness: "Privilege, to us, is like water to the fish, invisible precisely because we cannot imagine life without it" (as cited in Henfield \& Washington, 2012, p. 150).

This is problematic since 80\% (Howard \& Navarro, 2016) to 90\% (Cooper, 2003; Naman, 2009) of current and future educators are white, and their Whiteness often creates a divide between them and their students of color. While white teachers acknowledge an increasingly diverse student population, they frequently purport their often-limited experiences with people outside their race or ethnicity leaving them feeling ill-prepared for discussing race with children of color as well as reflecting on their own and their students' racial identities (Matias, 2013; Matias \& Liou, 2015; Milner \& Laughter, 2014). Symptoms of one’s Whiteness in the classroom can emerge as colorblind ideology, a false sense of equality, deficits-based thinking, lowered academic expectations, white messiah syndrome or white saviority, and superficial multicultural education (Henfield \& Washington, 2012; Ladson-Billings \& Tate, 1995; Matias, 2013; Matias \& Liou, 2015). These indicators emerge when teachers' Whiteness goes unchecked, or when white teachers feel uncomfortable or even "emotionally frozen to race and racism" (Matias, 2013, p. 78).

To avoid acknowledging race, white teachers often adopt a colorblind ideology. In being colorblind, teachers feel it is "far better to not 'see' race, to stress that you see . . . everyone . . . the 'same"' rather than be labeled a racist (Flintoff \& Fitzgerald, 2014, p. 565). In addition, white teachers may stress they treat their students equally or provide them equal treatment. White educators claiming to treat all their students the same "has been a common refrain, thus negating, dishonoring, and ignoring racial identities and realities of their students (and themselves)" (Milner \& Laughter, 2014, p. 343).

Despite the belief they do not see color and treat their students equally, white teachers who teach in urban schools often do so from a deficits-based perspective (Ladson-Billings \& Tate, 1995). According to Grantham and Ford (2003), white educators can become preoccupied with the differences they see in their students of color; in turn, they will categorize "these differences as impediments to learning" (as cited in Henfield \& Washington, 2012, p. 149). Accordingly, teachers may lower their expectations, decrease the difficulty of assignments, eliminate challenging 
readings or projects, or dilute the curriculum.

When students of color encounter difficulty in the classroom, their failing grades may be attributed to a conjured-up image of a challenging home life. In response, white educators often fall victim to "white saviority" where, as Matias (2013) explains, "white teachers believe they are loving their students of color when, in fact, they may be fulfilling their own narcissistic need to save them" (p. 72). Through a compulsion to serve in low-income, urban schools or through programs such as Teach for America (TFA) (Cann, 2015), this savior complex can further alienate them from their students and the community in which they teach (Dixson, Buras \& Jeffers, 2015; Matias, 2013; Matias \& Liou, 2015).

While white teachers may posit they want to understand their students of color better, they often search for a solution through a checklist or an in-service training to become more culturally competent (Matias \& Liou, 2015). The reality is that their white privilege often prevents them from reflecting on what their race has entitled them to-the fact that they don't have to think about their race-whereas race is often constantly on the minds of their children of color. This lack of reflection is what protects white teachers and what estranges diverse students from the curriculum, the classroom, and educational institutions. To discuss this divide, however, is uncomfortable, or even impolite, so it is better not to and to remain colorblind; thus, the cycle continues (Cooper, 2003; Henfield \& Washington, 2012).

So how do white teachers step outside their comfort zone and confront white privilege and white supremacy in the classroom setting? This article explores common beliefs espoused by white educators and deconstructs them using critical race theory (CRT). To be part of the solution, white teachers must examine their racial attitudes and beliefs. Through a CRT lens, educators can explore their patterns and behaviors and better understand how to dismantle white supremacist thinking.

\section{Theoretical Perspective}

Starting in the 1970s, critical race theory (CRT) scholars sought a way to explicate unaddressed oppression in society and the law. Derrick Bell laid the foundation in two law reviews: Serving Two Masters: Integration Ideals and Client Interests in School Desegregation Litigation (1976) and Brown v. Board of Education and the Interest Convergence Dilemma (1980) (Milner \& Laughter, 2014). According to Matsuda et al. (1993), there are six tenants that define CRT (as cited in Dixson \& Rousseau, 2005, p. 9):

1. Critical race theory recognizes that racism is endemic to American life.

2. Critical race theory expresses skepticism toward dominant legal claims of neutrality, objectivity, colorblindness and meritocracy.

3. Critical race theory challenges ahistoricism and insists on a contextual/historical analysis of the law ... Critical race theorists ... adopt a stance that presumes that racism has contributed to all contemporary manifestations of group advantage and disadvantage.

4. Critical race theory insists on recognition of the experiential knowledge of people of color and our communities of origin in analyzing law and society.

5. Critical race theory is interdisciplinary.

6. Critical race theory works toward the end of eliminating racial oppression as part of the broader goal of ending all forms of oppression.

Gloria Ladson-Billings and William Tate introduced CRT into education in their landmark publication Toward a Critical Race Theory of Education (1995), arguing that race was "under-theorized, not understudied" (Milner \& Laughter, 2014, p. 346). The premise of their work is that schools as an institution often deny the experiences, histories, and perspectives of people of color. Teachers typically approach children of color or urban schools from a deficits-based perspective. Furthermore, multicultural education is limited in its scope and depth, rendering it a superficial celebration of food, songs, or dance. CRT in its application to education seeks to disrupt these beliefs and practices, urging teachers and scholars to ask critical questions about institutional practices that create the inequities children of color experience. CRT also promotes the idea that children of color are not empty vessels; instead, they have a rich foundation developed through their experiences and cultural practices.

Finally, CRT "serves as a framework to challenge and dismantle prevailing notions of fairness, meritocracy, colorblindness, and neutrality” (Howard \& Navarro, 2016, p. 258). One of the ways to both challenge and dismantle these prevailing notions is through storytelling or creating a counter-narrative. The purpose of constructing an alternative narrative is to bring to the forefront voices that have been excluded from the master narrative. As 
Ladson-Billings (1999) explains, "adopting and adapting CRT as a framework for educational equity means that we will have to expose racism in education and propose radical solutions for addressing it" (as cited in Dixson \& Rousseau, 2005, p. 23). By applying CRT to my own qualitative experiences, I aim in this article to expose how white privilege and white supremacy have manifested in my own thoughts and actions as well as to inspire other white educators to take this reflective journey and approach toward comprehensive, transformative, and holistic education.

\section{Synthesis of Research}

In this section, prevailing racial attitudes and beliefs of white teachers are explored then contrasted and deconstructed using critical race theory (CRT) tenants and constructs. While CRT constructs often overlap with each other, they are discussed separately in this paper for clarification.

4.1 White Teachers May Espouse Living in a Post-Racial Society, But Critical Race Theory Recognizes Racism as Pervasive in Our Culture

Whites who remain unreflective of white privilege do not recognize a master narrative exists. This master narrative is everywhere-from the way the news is reported, to the way history is written, to the way movies play out. An essential function of critical race theory is utilizing voice to counteract the stories of the dominant group (Dixson \& Rousseau, 2005). Delgado (1989) argues whites—-the dominant group— “tell stories that are designed to 'remind it of its identity in relation to outgroups and provide a form of shared reality in which its own superior position is seen as natural'” (as cited in Dixson \& Rousseau, 2005, p.11). Part of this master narrative is that we live in a post-racial society. Whites accept this notion of a post-racial society, in part, because they want to offload uncomfortable feelings of guilt or shame. In believing race is no longer an issue, they do not have to accept responsibility or confront their racial attitudes. They also find support for this narrative due to the increasing visibility of people of color in mainstream media.

White teachers may extend this view to their schools, commenting on how diverse their staff, classrooms, schools, or communities are, but Goldsmith (2010) explains "On average, White students attend schools that are 21\% minority ... . [ [while] Black and Latino students' schools average $45 \%$ and $41 \%$ minority, respectively. Perhaps more importantly, many schools are composed almost entirely of either White, African American, or Latino students" (as cited in Jackson, Bryan \& Larkin, 2016, p. 67).

These statistics indeed tell a story, disrupting this narrative, then giving rise to the question as to why students remain so segregated long after Brown v. Board. Jackson et al. (2016) explain de facto segregation, caused by white flight and gentrification, as well as public housing, has contributed to the re-segregation of our schools (Jackson et al., 2016). White educators may exempt themselves from responsibility for matters outside the classroom, believing they have no control over community or societal issues; however, if we-white teachers—shift the blame, we avoid what is our responsibility: listening to our students. If we want to understand anything about the way in which children of color experience school, we must hear their stories.

Counter-narratives reflect the lived experiences of people of color and challenge the dominant or master narrative. The way in which counter-narratives manifest in the classroom varies, but they can appear as a seemingly innocent comment. Jackson et al. (2016) describe such an encounter with an elementary student who told her white teacher, "I'm not supposed to like white people, but I like you" (p. 64). I have heard similar statements from my African American and Latino students, such as "You're okay for a white lady," or "I used to hate white people, but I like you." Because I had not yet reflected on my racial attitudes, my responses to such statements revealed a post-racial stance: "Well I'm glad you like me, but what does my race have to do with it?"

Through my response, I inadvertently usurped my students' stories. What I was actually saying to my students, indirectly, is that Race should not have anything to do with your liking me. We live in a world where all races get along, where we've elected a Black president, where race shouldn't matter anymore. My post-racial narrative took precedence over their experiences, leaving no room for their voices. As soon as I said those words, they dropped the conversation. What their counter-narrative and the counter-narrative of the elementary student reflect, however, is that race has everything to do with it. To truly hear our students of color, we cannot be defensive like I was. Instead, we-white educators - must remove ourselves from our own ethnocentric bias and place our students at the center of the story.

The students' comments, according to Jackson et al. (2016), reveal a process many children of color experience growing up: racial socialization. When parents of color racially socialize their children, they may share their own 
experiences with implicit or explicit bias or engage in direct instruction about how to handle discrimination. Racial socialization is also a process whereby parents teach their children pride in their race through oral history, customs, spirituality, and celebrations (Thomas \& Blackmon, 2015). Another component of racial socialization is the promotion of mistrust. According to Jackson et al. (2016), this process is distinct from preparation for experiencing bias because parents provide no direction for action. Instead, they offer social distance warnings about groups with which their children should be wary and cautious. The motivation for sending messages of social distance towards whites is well documented in the media between white police officers and people of color. When African American and Latino parents explain to their children being "overly polite and articulate" could save their lives, it is no wonder students of color are distrusting of whites (Thomas \& Blackmon, 2015, p. 84).

When my students shared their comments, they invited this "white lady" into their world where they have been instructed, with good reason, not to trust white people. Despite their better judgment, they like me, and they are curious about that phenomenon. CRT implores us to see beyond the post-racial narrative and to be equally curious about the lives of our students through their counter-narratives and storytelling. To claim we live in a post-racial society is to negate and dismiss the lived experiences of our children of color.

4.2 White Teachers May Believe That Because They Teach in a Diverse, Inner City School, They Cannot Be Racist; However, The Intersection of Race and Property Creates a Tool Through Which We Can Analyze School Inequity

\subsubsection{Charter Schools}

Part of what drew me to Los Angeles was the energizing, vibrant charter school movement. Charter schools account for three of four schools in Los Angeles where I taught, which promoted academic rigor, college readiness, and longer school days. I believed joining this movement meant being a part of a larger movement that would transform education for children of color living in poverty. What I did not understand at the time was the underlying issues of charter reform that can only be understood when intersecting race and property. While the principals of all three schools were women of color, many of the staff looked like me, young white women. In all three schools, the student population was exclusively represented by children of color-two schools with an all Latino population, and one school with an all African American population. In contrast, the founders of all three agencies were white men, and the money that funded these charter management organizations (CMOs) came from white philanthropic organizations such as the Broad Foundation and the Gates Foundation.

Under the guise of neoliberal reform, CMOs can have a colonizing effect on education for families of color. Moving into impoverished African American and Latino neighborhoods, these CMOs take over historically "failing" schools, doing for families of color what they supposedly cannot do for themselves. Ladson-Billings and Tate (1995) explain, "The grand narrative of U.S. history is replete with tensions and struggles over property—in its various forms. From the removal of Indians (and later Japanese Americans) from the land, to military conquest of the Mexicans, to the construction of Africans as property, the ability to define, possess, and own property has been a central feature of power in America” (p. 53).

The institution of education is no different. Dixson, Buras and Jeffers (2015) took an in-depth look at the impact of a CMO take-over in post-Katrina New Orleans. While portrayed as an overhaul of a failing system, the African American community described the process as an assault when 7,500 mostly African American paraprofessionals, teachers, and administrators of the Orleans Parish School District were fired and replaced by predominately young, white transplants from organizations like Teach for America (TFA), New Leaders for New Schools, and the New Teacher Project (Dixson et al., 2015). Community members described those who replaced veteran African American educators as "carpet baggers . . . . [which is] appropriate if we consider . . . the displacement and replacement of Black veteran teachers and educators for the transplanted, mostly young and White 'northerners' who seized control of public schools at a time of incredible collective emotional and infrastructural trauma” (Dixson et al., 2015, p. 289). The African American community of New Orleans perceived this take-over of public education as based on white supremacist beliefs that African Americans are incapable of teaching their own, thus needing a white savior to lift them out of ignorance and poverty (Dixson et al., 2015).

\subsubsection{White Messiah Syndrome}

The persona of whites as a savior has long been visible in U.S. history and its media. Matias and Liou (2015) explain that "historic altruism" has glorified whites who have given up their safety or lives in the fight for freedom for African Americans. This message has been perverted and recycled, masking "white messiah syndrome" which "advances [whites'] moral authorities and co-creates the saving mentality as formidable justifications to make a place like urban schools into rescue missions” (Matias \& Liou, 2015, p. 604-605). 
Perhaps the most painful realization of this journey for me is recognizing that I have taken on and perpetuated the white savior syndrome. Over the years, I have had many conversations with my students about their grades and all the implications for their future-college, jobs, goals, income—but one critical conversation took a sharp turn when I assumed the role of my students' white savior. I described to my students how my mother dropped out of college when she became pregnant with me, then put me in foster care immediately after my birth. After working for almost a year, she had some money and a career path and could take me back, but had my grandmother not let my mother and I live with her, I would still be in foster care, or we would be on welfare. While this admission was intended as a point of connection with my students, it represents a raw and humbling example of white privilege and white messiah syndrome at work. As Matias and Liou (2015) explain, I was "motivated to save urban students of color from a reality that is far different from" my own, one that has never put me "in doubt in social, educational, or professional situations” (p. 603).

As I look back on this moment now, how dare I compare my experiences or my mother's to those of my Latino students? I knew nothing about their lives, what their parents endured immigrating to this country, or what it was like living in the U.S. as an undocumented immigrant. More importantly, I knew nothing about living as a person of color, yet I spoke to them as if I did and as if my hardships mirrored their own. In sharing that story, I was essentially telling my students, Do well in school so you don't have to make choices like my mom! and If I could go to college, so can you, so pull yourselves up by your bootstraps! as if it were that simple. As Matias and Liou (2015) point out, in attempting to save children of color, white educators "seldom critically analyze their White privileges and role as participants in this racist and capitalist society. That is, why is it they feel they have the right to save?” (p. 605).

\subsubsection{Interest Convergence}

To answer the question above, we must delve deeper into the intersection of race and property to understand interest convergence. This concept can best be understood through an alternative teacher-credentialing program, Teach for America (TFA). According to Cann (2015), TFA recruits recent college graduates from the top 400 universities in the country, and after a five-week intensive training, places them in low-income schools. While TFA recruits are predominately white, $90 \%$ of the students they teach are students of color, and almost all are low-income (Cann, 2015). The program sells to college grads the idea of making "a real difference in the world" and TFA alum state they joined because they were "motivated to do 'something 'real'” and "do 'something valuable for society' and to 'mak[e] a difference'”' (Cann, 2015, p. 289).

In the three charter schools where I taught, TFA teachers taught alongside me. All were passionate, motivated, intelligent, but as Cann (2015) notes, nearly $80 \%$ of them leave after three years or less, and, sadly, "take their learning (as well as the resources invested in their recruitment and training) with them” (p. 302). The reason these white educators enlist in a program such as TFA then leave the classroom in such a short amount of time is often due to interest convergence. Cann (2015) explains social justice-driven legislation and policy are only successful when they serve the interests of those who are already in power. In other words, while TFA appears to improve the educational outcomes of youth of color, the program actually benefits the white teachers. There are several ways in which their interests are served. First, recruits receive a full salary in addition to the benefits credentialed educators receive-health and dental insurance as well as retirement. Second, with AmeriCorps support, interns are eligible for a scholarship valued at up to $\$ 11,000$ they can apply towards past or future education (Cann, 2015). In addition, during the time served in TFA, AmeriCorps will pay any interest accrued on recruits' student loans (Cann, 2015). Next, if they are relocating, TFA members can apply for interest-free loans valued at up to $\$ 6,000$ for moving costs (Cann, 2015). Finally, as a current TFA member or as a TFA alum, more than 200 graduate schools will waive application fees or offer financial awards to in-coming students (Cann, 2015). Labaree (2010) argues “TFA's approach to teaching reinforces an old and dangerous vision of teaching as a form of slumming, a missionary effort by the White middle class to elevate minorities and the lower classes through the medium of education" (as cited in Cann, 2015, p. 310).

For whites who teach African American and Latino children, and especially those of us who teach children of color at a charter school, we must ask ourselves Why?. Are we there to repeat the historical narrative of white saviors, to feel better about ourselves as we "help the less fortunate," or to advance our careers? As we stand before our children of color, do we perceive them as under-educated, soon-to-be-dropouts doomed to live in a cycle of poverty? Without reflecting on our purpose, we-white educators - do not serve children of color or their communities; instead, we perpetuate the cycle of colonizing, saving, and profiting at the expense of our students. Without considering what our race entitles us to, we minimize our intentions, convincing ourselves of the righteousness of our actions. 
4.3 White Teachers Will Often State They Are Colorblind, But Critical Race Theory Expresses Skepticism Toward Dominant Legal Claims of Neutrality, Objectivity, Colorblindness, And Meritocracy

The claim of colorblindness is pervasive among white teachers. In her 2003 study, Cooper identified this claim even amongst white educators regarded as highly effective teachers of Black children by African American parents and administrators. While being extremely committed to their students and the students' families, the teachers never discussed race with their students. They provided two reasons why: they believed "the most equitable stance toward race was a colorblind one .... [and] . . . they feared such discussion would be misunderstood by administrators, parents, and the community at large” (Cooper, 2003, p. 424).

Cooper (2003) explains that failing to discuss race openly contradicts what research and literature report about effective teachers of children of color. Ignoring race in the classroom continues the oppressive cycle. To change the way race is understood, it must be openly addressed (Jackson, Bryan \& Larkin, 2016). This failure on the teachers' part "undermined [their] espoused beliefs and practices around respect for and empathy with the Black community at large, including a willingness to learn from it" and is a serious limitation (Cooper, 2003, p. 425). According to Dixson \& Rousseau (2005), what makes this silencing so damaging is that non-whiteness is viewed as "a malady.” In other words, white, middle-class norms dictate not to see and certainly not to discuss differences and abnormalities. Think of children who, for the first time, see a person with a physical disability. Their desire to point and ask questions is powerful; however, they are instructed not to see, not to ask because it is impolite. As adults, we repeat the same pattern with our children of color. Thompson (1998) emphasizes the indirect message white educators are sending their students: "politely pretending not to notice students' color makes no sense unless being of different colors is somehow shameful” (as cited in Dixson \& Rousseau, 2005, p. 16).

\subsubsection{Moving Beyond "Multicultural ” Education}

To counteract this silencing, white educators must move past multicultural education, the current tool that exists for those who do attempt to address race in the classroom. The problem with multicultural education is that it does not typically allow for engagement in critical discussions. Instead, it reduces race and ethnicities to superficial renderings of foods, songs, folktales, and dances and purports a political ideology of tolerance among differences while ignoring the tensions which exist within those differences (Ladson-Billings \& Tate, 1995).

This lack of critical interrogation benefits whites. If questions are not asked, if dialogue does not occur, if we can superficially appreciate our differences, then no changes are necessary because, in theory, we all get along. There is nothing transformative about this practice, and it "is mired in liberal ideology that offers no radical change in the current order” (Ladson-Billings \& Tate, 1995, p. 62). What white educators need to move towards is culturally responsive teaching, which redefines how we look at and work alongside children and communities of color.

As one of my former charter school principals prepared for her first year as a school leader, she shared with us, her new staff, some practices that helped her previous school achieve Compton Unified's first-ever California Distinguished School award. The first month of school, the school leadership created a parent advisory committee and asked for their opinions about the school's needs, particularly in rewriting the discipline policy. Next, all students engaged in an intensive study about their school - the person for whom the school is named, the school's history, the neighborhood's history, and history reflecting the school's demographics (Latino and African-American). Latino and African American history were weaved into lessons throughout the school year. At the end of the month-long study, the students presented what they learned to their families at a parent night. These two actions created tremendous buy-in from the students and the parents.

Understanding their school and their neighborhood helped the students feel a sense of pride and engaging all parents in a meaningful way increased their commitment to the school. The school leadership changed the narrative of low-performing Compton schools, disengaged youth, and uninvolved parents by immersing students in the history of the school, inviting parents to the table and asking for their opinions, and creating teachers and storytellers out of the children. Rather than ignoring the racial differences of the children, this became both a point of inquiry and an impetus to connect with families and the community. The children's background and the community's history became a resource and a springboard for critical conversations about race. Most importantly, this provided both parents and students a voice.

Another way of addressing race in the classroom occurs through using a culturally relevant approach to challenge the master narrative in specific course content areas. Matias and Liou (2015) described how Matias spotlighted race in her $11^{\text {th }}$-grade history class, analyzing how people of color have been positioned poorly to benefit institutions. Matias explicated a particular lesson on the U.S. colonization of the Philippines during the post-Spanish-American War era. 
Recognizing her history textbook provided a one-sided account, Matias offered alternative perspectives, supplementing the reading with additional sources such as a chapter from The Colonizer and the Colonized, President McKinley's Benevolent Assimilation speech, images of caged Filipinos at the 1904 St. Louis World Fair, and yellow journalists' depictions of Filipinos. She urged her students to question how "positioning native Filipinos in this racialized depiction" led to American support of the colonization of the Philippines (Matias \& Liou, 2015, p. 612). In analyzing these events from the CRT perspective, Matias and her students were able to discuss race freely, specifically how events throughout history have benefited from structural racism. Matias described these discussions as "redemptive" and "healing" because they provided a vehicle to challenge Eurocentric thinking and storytelling that so often dominate history courses (Matias \& Liou, 2015, p. 613).

4.4 Many White Teachers Claim They Treat All Students Equally; However, Critical Race Theorists Assume Racism Influences Group Advantage and Disadvantage

To understand equality in the classroom, restrictive and expansive views of equality must first be understood. Crenshaw (1988) explains that the expansive view stresses equality as a result of action, examining real consequences for people of color (as cited in Dixson \& Rousseau, 2005). Those who interpret law from an expansive view push the courts and institutions to use the law to eradicate racism and oppression. The restrictive view, however, sees equality as a process rather than an outcome and views anti-discrimination law as a means of prevention instead of correction of "present manifestations of past injustice" (Crenshaw as cited in Dixson \& Rousseau, 2005, p. 1341-1342). Additionally, injustices are interpreted as isolated incidents rather than pervasive problems.

Rousseau and Tate (2003), in seeking to understand the intersection of teachers' understanding of equality and student outcomes, observed low-track high school mathematics courses where children of color-especially African American students-were overrepresented. Their observations revealed a pattern in the white teachers' understanding of equality as most of these teachers stated that they worked with, responded to, or treated all the students equally. Treating students the same was an especially salient response to equity and diversity issues in the classroom; none, however, discussed student outcomes (Rousseau \& Tate, 2003). When presented data that showed considerable racial differences in outcomes, most teachers did not acknowledge race played a role, and some even denied such a pattern existed (Rousseau \& Tate, 2003). One teacher commented, "I don't think that has really come up. I mean, I have never, I don't feel like I have ever been faced with any kind of issues based on equity or diversity" (Rousseau \& Tate, 2003, p. 214). For these reasons, Rousseau and Tate (2003) determined the teachers applied a process-oriented or restrictive view of equality.

In contrast to the teachers' self-promoted view of equality in their classrooms, the researchers revealed a highly inequitable approach. One afternoon in particular, there were only four students in the class, three of whom were African American. After the students started on their bookwork, the white student asked permission to go to the nurse's office and spent the majority of the period there. One of the African American students, after attempting to start on his work, asked the teacher if another student in the class could help him, but she did not allow him to do so. He struggled the remainder of the period to complete his work and did not ask for nor receive assistance from the teacher. Another African American student worked independently and struggled as well. Like the boy, she neither asked for nor received the teacher's help. As the students worked, the teacher remained at her desk and worked on a project for an upcoming unit. The only time she interacted with the students was when the white student returned from the nurse's office and asked if he could work on the project. The teacher said he could, and he worked on that for the remainder of the period. After the students left, the teacher explained she was intentionally taking a hands-off approach and would not offer help unless the students demonstrated initiative by asking for it. Rousseau and Tate (2003) indicated their observations were not unique to this class or this teacher but instead revealed a pervasive pattern of what they described as "allowing students to fail" (p. 214). The students, who were disproportionately Black males, were allowed not to work providing they did not disrupt the class (Rousseau \& Tate, 2003).

The white teachers' application of restrictive equality did not promote or allow for self-reflection about their interactions with their students since, from their perspective, everyone was treated the same. The students who took responsibility for their learning by asking for assistance received instructional support, and those who did not were subject to the "hands-off approach" (Rousseau \& Tate, 2003). Because the students were not treated any differently based on their race, the teachers did not see their approach as problematic. This view prevented them from analyzing how their actions may contribute to disproportionate outcomes. An expansive view of equality would not tolerate this type of thinking. Racially disproportionate student outcomes would elicit teacher reflection on instructional practices that could be interpreted as barriers or oppressive by students of color, such as not helping the students unless they requested it. 
For those few white teachers who did acknowledge racially disproportionate outcomes, the students' socioeconomic status or the family's lack of value in education was identified as the culprit (Rousseau \& Tate, 2003). With this mindset, white teachers again did not reflect on their practices. Instead, the blame was deflected, and racial stereotypes were reinforced such as the uneducated, un-invested African American parent. Educational institutions, also typically restrictive in their practice of equality, accept this connection between race, socioeconomic status, and poor student outcomes, leaving unquestioned how their practices contribute to unequal results. If these positions are left uninterrogated, students of color are left carrying the burden and are further disenfranchised from the classroom.

\section{Discussion}

The question posed at the beginning of this paper was how do white teachers step outside their comfort zone and confront white privilege and white supremacy in the classroom setting? The research presented dissects white supremacist attitudes and beliefs white educators often embrace, and while some may want to believe they are the exception, they are not. We are all culpable; therefore, we are all responsible for instituting change. In the face of constant shifts in education, teachers can be resistant to yet another alteration in the classroom; however, this change is more than just another mandate. This is, ultimately, about the kind of educator and person we want to be.

\subsection{Self-Initiate}

White educators do not have to wait for administrators to institute professional development, or for universities to offer a cultural competency course to create radical change. We can simply begin with a curiosity about our attitudes towards race, examining from where those beliefs derive. For example, what connections do we make between our students' race and socioeconomic status, or between their race and work ethic? What assumptions do we make about our students' parents? From where did those ideas originate? Like our students of color, we-white educators-have been racially socialized. In becoming aware of this, we can more readily check our white privilege and white supremacist thinking. Equally important, whites must also consider how Whiteness manifests in history for people of color, such as Matias' lesson on the U.S. colonization of the Philippines, and how that history plays out in the present. This allows us to be more cognizant of the master narrative and how it continues to evolve-for example, the current assertion that we live in a post-racial society. White teachers who are culturally competent will reject such a claim, understanding this negates and dismisses the lived experiences of children of color.

\subsection{Listen to Our Students}

When students of color share their experiences, they are inviting us into their world. Holding space for their stories can present a challenge for white teachers. We may want to defend our behavior or thoughts, or we may become uncomfortable because we somehow feel implicated in the statements they make. All white educators have inadvertently upheld and reinforced the master narrative, and to stifle our students' stories because of our discomfort or defensiveness is to strengthen that narrative. Instead, we must make our students' stories about their lived experiences, not about our ego. To allow our curiosity about our students' experiences to supersede our ethnocentric thoughts and feelings is to put our white privilege in check. Students and families of color are not responsible for making white educators feel better about themselves; on the contrary, whites are responsible for helping to bear the burden people of color carry every day. In listening to our students, we cultivate empathy and begin to dismantle our white supremacist thinking. Apart from this, however, these "stories must move us to action and the qualitative and material improvement of the educational experiences of [our students] of colour" (Dixson \& Rousseau, 2005, p. 13).

\subsection{Self-Interrogate}

As white teachers open their classrooms to conversations about race, they will learn how to see the world through their students' eyes. As they do, they will see and experience vicariously what students of color do every day, becoming cognizant of circumstances and situations they have never before considered. With this disruption in their narratives, white educators, moved to action, must interrogate their motivations and beliefs. For example, when examining student data, what does it reveal about our biases? How are our biases contributing to that data? How do our practices disenfranchise students of color? Without critically reflecting on our racial attitudes and beliefs, and how they play out in the classroom, we-white educators - are merely upholding the ideology of restrictive equality while allowing students to fail. Or, worse, we hold the students' socioeconomic status responsible, offloading any personal responsibility. These unchecked, un-interrogated biases do not serve children of color or their communities; instead, they hold students of color hostage to an uncertain present and future.

\subsection{Become a White Ally}

To create true and lasting change for students of color, we must become a white ally. Being a white ally requires 
white educators to remain vulnerable, rejecting our white privilege and challenging the inequities when we recognize them. This can be unpopular among our white peers, and we may face alienation; however, when we do not confront injustice, we remain complicit, upholding dominant white ideology. Being a white ally also demands continuous self-reflection, examining and questioning how our biases may be at work, or how they may manifest in the work of colleagues or institutions. When we engage in these self-reflective endeavors, we cannot help but become disturbed or outraged, propelling us to dismantle a system that disenfranchises students of color. As Matias (2013) explains, these feelings emerge from "a deep anger for human pain, a swift refusal to let it continue to happen. Only then does culturally responsive teaching turn into a project of the self and one's relationship to society instead of a project to merely identify effective practices of the 'Other'” (p. 78). In other words, when white teachers refuse to stand idly by and begin to work towards expansive equality for students of color, we are working towards a betterment of society and ourselves. Rather than checking off a cultural competency list, we are transforming ourselves, our students, and the community around us.

\section{Conclusion}

The literature presented challenges the attitudes and beliefs held by many white teachers. For far too long we have controlled the master narrative in education, identifying our students of color as children in need of saving, and congratulating ourselves for being their saviors. We may want to believe our seemingly well-intentioned equal treatment or colorblind views of our students of color are driven by progressivism, but, in fact, those actions are born from white supremacist notions. White supremacy is not about individual, prejudicial acts; it is about a covert system of unspoken rules that guide the way white educators teach and interact with students of color, leaving the teacher empowered and the students of color marginalized. To blame an African American or Latino student's performance on socioeconomic status, unengaged parents, language proficiency, or even intelligence is to keep our Whiteness intact. To relinquish this type of thinking, we must put the responsibility on ourselves which will then give rise to the answering the question, "What am I doing to disenfranchise this student?" This question has the potential to initiate a journey of self-reflection for white teachers that can permanently alter the way we teach and the way we live.

\section{References}

Cann, C. N. (2015). What School Movies and TFA Teach Us About Who Should Teach Urban Youth: Dominant Narratives as Public Pedagogy. Urban Education, 50(3), 288-315. https://doi.org/10.1177/0042085913507458

Cooper, P. M. (2003). Effective White Teachers of Black Children. Journal of Teacher Education, 54(5), 413-427. https://doi.org/10.1177/0022487103257395

Dixson, A. D., \& Rousseau, C. K. (2005). And we are still not saved: critical race theory in education ten years later. Race Ethnicity and Education, 8(1), 7-27. https://doi.org/10.1080/1361332052000340971

Dixson, A. D., Buras, K. L., \& Jeffers, E. K. (2015). The Color of Reform. Qualitative Inquiry, 21(3), 288-299. https://doi.org/10.1177/1077800414557826

Flintoff, A., Dowling, F., \& Fitzgerald, H. (2015). Working through whiteness, race and (anti) racism in physical education teacher education. Physical Education and Sport Pedagogy, 20(5), 559-570. https://doi.org/10.1080/17408989.2014.962017

Harper, S. R., \& Davis, C. H., III. (2012). They (Don't) Care about Education: A Counternarrative on Black Male Students' Responses to Inequitable Schooling. Educational Foundations, winter-spring, 103-121. Retrieved February 15, 2017, from http://search.proquest.com/docview/1020696932/fulltextPDF/3E93487D2C46424BPQ/1?accountid=10920

Henfield, M. S., \& Washington, A. R. (2012). "I want to do the right thing but what is it?": White Teachers' Experiences with African American Students. The Journal of Negro Education, 81(2), spring, 148-161.

Howard, T. C., \& Navarro, O. (2016). Critical Race Theory 20 Years Later: Where Do We Go From Here? Urban Education, 51(3), 253-273. https://doi.org/10.1177/0042085915622541

Jackson, T. O., Bryan, M. L., \& Larkin, M. L. (2016). An Analysis of a White Preservice Teachers Reflections on Race and Young Children Within an Urban School Context. Urban Education, 51(1), 60-81. https://doi.org/10.1177/0042085914542659

Ladson-Billings, G., \& Tate, W. F., IV. (1995). Toward a Critical Race Theory of Education. Teachers College Record, 97(1), fall, 47-68. 
Ledesma, M. C., \& Calderón, D. (2015). Critical Race Theory in Education. Qualitative Inquiry, 21(3), 206-222. https://doi.org/10.1177/1077800414557825

Matias, C. E. (2013). Check Yo'Self Before You Wreck Yo'Self and Our Kids: Counterstories from Culturally Responsive White Teachers? . . . to Culturally Responsive White Teachers! Interdisciplinary Journal of Teaching and Learning, 3(2), 68-81.

Matias, C. E., \& Liou, D. D. (2015). Tending to the Heart of Communities of Color: Towards Critical Race Teacher Activism. Urban Education, 50(5), 601-625. https://doi.org/10.1177/0042085913519338

Milner, H. R., \& Laughter, J. C. (2014). But Good Intentions are Not Enough: Preparing Teachers to Center Race and Poverty. The Urban Review, 47(2), 341-363. https://doi.org/10.1007/s11256-014-0295-4

Naman, W. (2009). Who Should Teach Black Students? Research on the Role of White and Black Teachers in American Schools. Ethnicity and Race in a Changing World, 1(2), 26-39. https://doi.org/10.7227/erct.1.2.3

Rousseau, C., \& Tate, W. F. (2003). No Time Like the Present: Reflecting on Equity in School Mathematics. Theory Into Practice, 42(3), 210-216. https://doi.org/10.1353/tip.2003.0035

Thomas, A. J., \& Blackmon, S. M. (2015). The Influence of the Trayvon Martin Shooting on Racial Socialization Practices of African American Parents. Journal of Black Psychology, 41(1), 75-89. https://doi.org/10.1177/0095798414563610 